Tadeusz KAWKA

Fish processing

\title{
ANALYSIS ON DETERMINATION OF HIGHEST WORKING \\ PARAMETERS OF CIRCULAR CUTTERS \\ IN MECHANICAL PROCESSING OF FISH
}

\section{BADANIA NAD USTALENIEM OPTYMALNYCH PARAMETRÓW NOZZY TARCZOWYCH DO MECHANICZNEJ OBRÓBKI RYB}

\author{
Institute of Marine Resources Exploitation
}

The analysis of cutting force in relation to kinematic conditions of raw fish cutting are presented in this paper. Method of indirect measurements is applied in these analysis. It ascertained that, the cutting speed affects the value of cutting force. It determined the highest working parameters for circular cutters in fish beheading. The results of analysis are presented graphically.

\section{INTRODUCTION}

Cutting is one of the basic operations as a component in fish processing.

Tools of various kinematic and geometric parameters are generally used for cutting. This results from the empiric explorations directed towards the efficient solutions, and it is consequent to lack of suitable basic investigations. This work presents an attempt in determination of relations between the kinematic parameters and cutting force during mechanical dressing of fish. The investigations had been carried-out in order to define the value of cutting force in relation to the predetermined conditions of cutting and to 
evaluate highest parameters for processing operations. An application of highest parameters and the knowledge of forces which act on fish during its mechanical division, allow to select the suitable arrangements in drive and in transportation systems.

The previous attempts to define theoritically the value of cutting force in fish material have not entirely comprehended the problem.

The experiments on fish cutting had been conducted by Jakubov (1964), Žilin (1963, 1966) and Romanov (1963). Those scientists applied various methods. Basic definitions were not strictly and uniformy precised. Excluding the experiments based on static methods which prove to be not applicable for determination of circular cutters operation, not much is being left from achievements of experiments already performed.

\section{DEFINITION OF CUTTING FORCE}

Owing to complex quantity of technical and technological factors which appear during the cutting process, the precision of range is wery vital for investigations. Usually accepted for definition of material strength is the ratio of cutting-force value to crosssection value. It is assumed that, only the stresses acting in plane of cutting process.

To define exactly the strength of material in relation to fish body is very difficult. This is primarily due to organic origin of raw material distinct for its non-uniform structure. Mechanical properties depend then from situation of division plane. At the place of cutting appears a state of local stresses. Thus, for evaluation of resistance in material cutting must be assumed the value of limit stresses distributed on cutting line, at which division of tissue is effected.

To evaluate the stresses, it is necessary to determine the pressure of cutting edge; in this case is assumed the force of cutting edge on material. This force is distributed on line of cutting edge. An evaluation of pressure can be obtained experimentally only. With a view that the results may be applicable in practice, the experiments had been carriedout in strict conjunction with technology used in processing of fish material.

In cutting, the interrelated forces between cutting blade and material may be reduced to one resultant force $\mathrm{P}$. This force comprises: resisting force of spring and plastic deformation P'; friction force between blade and material T; adhesion force $\mathrm{P}^{\prime \prime}$. This may be expressed by formula:

$$
P=P^{\prime}+2\left(T+P^{\prime \prime}\right)
$$

Any possibility of cutter jamming within the cut material is practically eliminated. This assumption results from relatively small cross-section of fish. Design of cutting tool results in slight adhesion of material to the sides of blade during the process of cutting. For simplification of theoritical analysis, the friction force $\mathrm{T}$ and adhesion force $\mathrm{P}$ " are neglected. The cutting force $\mathrm{P}$ is brought to one point $\mathrm{A}$, however, in reality is distributed along the total length of working cutting blade. The force $\mathrm{P}$ reflects the force necessary for division of the examined sample.

It is assumed for mathematical evaluations that, a fish body represents uniform material of the same strength. Thus, the force P may be calculated according to formula: 


$$
P(t)=\int_{0}^{L(t)} p \cdot d L
$$

where:

$\mathrm{L}$ - length of cutting blade at moment $\mathrm{t}$

$\mathbb{P}$ - unit cutting force corresponding to destructive stresses in material.

For unit cutting force, assumed the acting on blade force which is necessary for cutting $1 \mathrm{~cm}$ of a fish body. To make the above equation absolutely real, the following assumptions must be considered:

- edge of cutting blade is geometrically uniform on total length

- profile and dimensions of micropoints on cutting edge are uniform.

Depending on assumed reference system, the cutting force $\mathrm{P}$ may be divided as, tangential $\mathrm{P}_{\mathrm{o}}$ and normal $\mathrm{P}_{\mathrm{n}}$ in relation to cutter, and as horizontal $\mathrm{P}_{\mathrm{x}}$ and vertical $\mathrm{P}_{\mathrm{y}}$ components in relation to sample in cutting.

The force $P_{0}$ is tangentially directed to edge of cutting blade and causes the twisting moment on axi and of cutter. The force $P_{n}$ is derected towards the centre of cutter and causes the deflection of cutter axi in plane of its action. The assumed system is static.

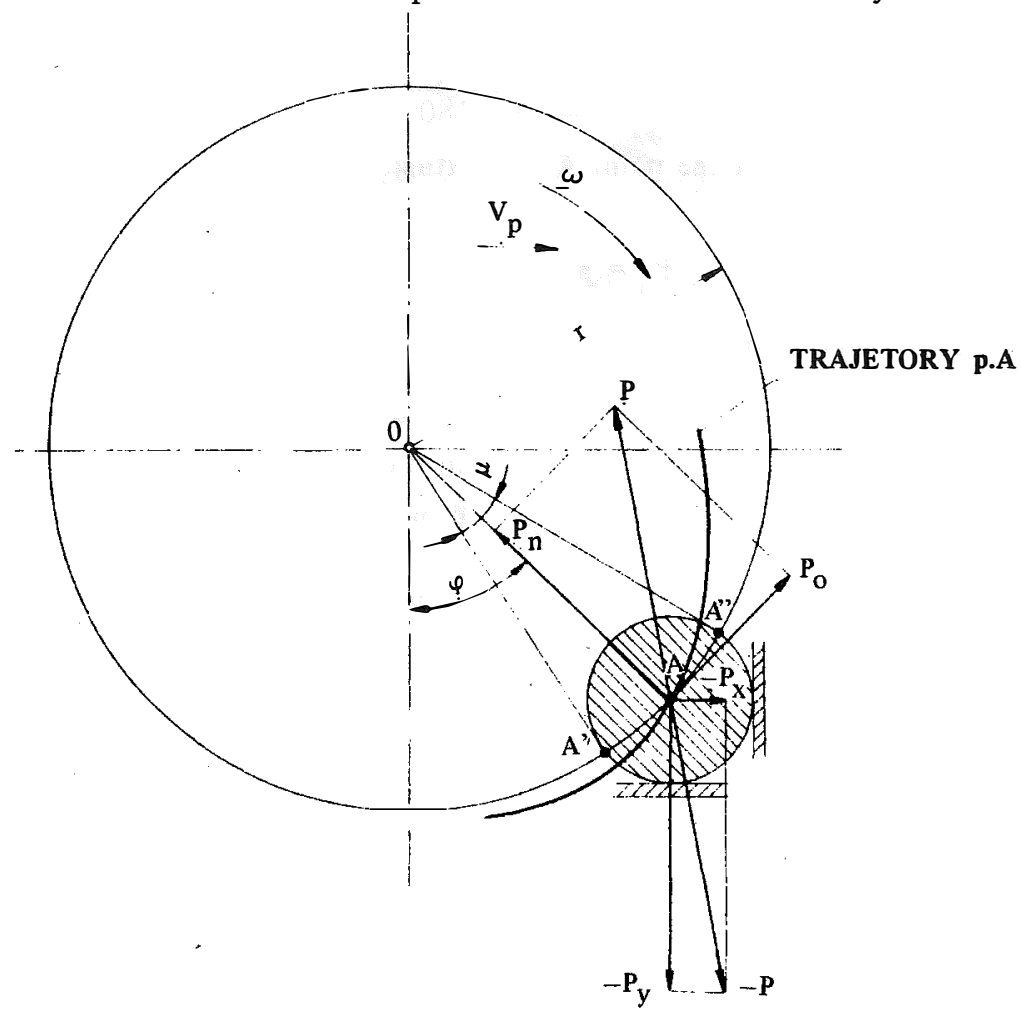

Fig. 1. Operation diagram of circular cutter, defining the cutting forces 
Assuming that $\mathrm{v}_{\mathrm{o}} \gg \mathrm{v}_{\mathrm{p}}$, deflection of acting direction of force $\mathrm{P}_{\mathrm{o}}$ in dynamic system is minor, and the resulting differences of moments are sufficiently negligeable. Thus, the accepted system (Fig. 1) may be considered as substantially precise for practical calculations.

The forces $\mathrm{P}_{\mathrm{x}}$ and $\mathrm{P}_{\mathrm{y}}$ act on material in cutting on directions perpendicular to plane of resistance. The turns of forces depend on direction of cutter revolutions in relation to material in cutting. Analysing Fig. 1, it is apparent that the values of particular force components are strictly relative to situation of sample at cutting edge. This relation is defined by mid-angle situated between the selected point $A$ on cutting blade in sample and the vertical axi of cutter.

It assumed that, at the moment $t$, the line of cutting is spanned on length $A^{\prime} A$ " and the reduced cutting force is applied at point $A$. Length $A^{\prime} A^{\prime \prime}$ on arc amounts to:

$$
\mathrm{A}^{\prime} \mathrm{AA} "=\mathrm{r} \cdot \frac{\pi}{180} \cdot \mu^{\circ}
$$

where:

$\mu$ - mid-angle of length $A^{\prime} A^{\prime \prime}$

$r$ - radious of cutter.

Tangential force $\mathrm{P}_{\mathrm{O}}$ at point $\mathrm{A}$ is resulting from tangential unit cutting force distributed on arc A'A":

$$
\mathrm{P}_{\mathrm{o}}=\mathrm{p}_{\mathrm{o}} \cdot \mathrm{r} \cdot \frac{\pi}{180} \cdot \mu^{\circ}
$$

Normal component $\mathrm{P}_{\mathrm{n}}$ at the point $\mathrm{A}$ is resulting from normal unit force distributed on arc A'A":

$$
\mathbb{P}_{\mathrm{n}}=\mathrm{p}_{\mathrm{n}} \cdot \mathrm{r} \cdot \frac{\pi}{180} \cdot \mu^{\circ}
$$

Total cutting force amounts to:

$$
\mathrm{P}=\sqrt{\mathrm{P}_{\mathrm{o}}^{2}+\mathrm{P}_{\mathrm{n}}^{2}}
$$

The horizontal and vertical components are obtained on the axi of coordinates xy:

$$
\begin{aligned}
& \left(\mathbb{P}_{\mathrm{x}}\right)=\left(\mathbb{P}_{\mathrm{o}} \cos \varphi\right)+\left(\mathbb{P}_{\mathrm{n}} \sin \varphi\right) \\
& \left(\mathbb{P}_{\mathrm{y}}\right)=\left(\mathbb{P}_{\mathrm{o}} \sin \varphi\right)+\left(\mathbb{P}_{\mathrm{n}} \cos \varphi\right)
\end{aligned}
$$

and the total cutting force:

$$
\mathbb{P}=\sqrt{\mathbb{P}_{x}^{2}+P_{y}^{2}}
$$

\section{METHOD}

Material. In majority the catches comprise the fish of cod sp., herrings and Norway haddock. Shape of these fishes approaches in its profile and ideal model of stream-lined mass (Fig. 2). The spindle profile fish cross-section is similiar to circle and this allows to apply some simplification in final calculations. 

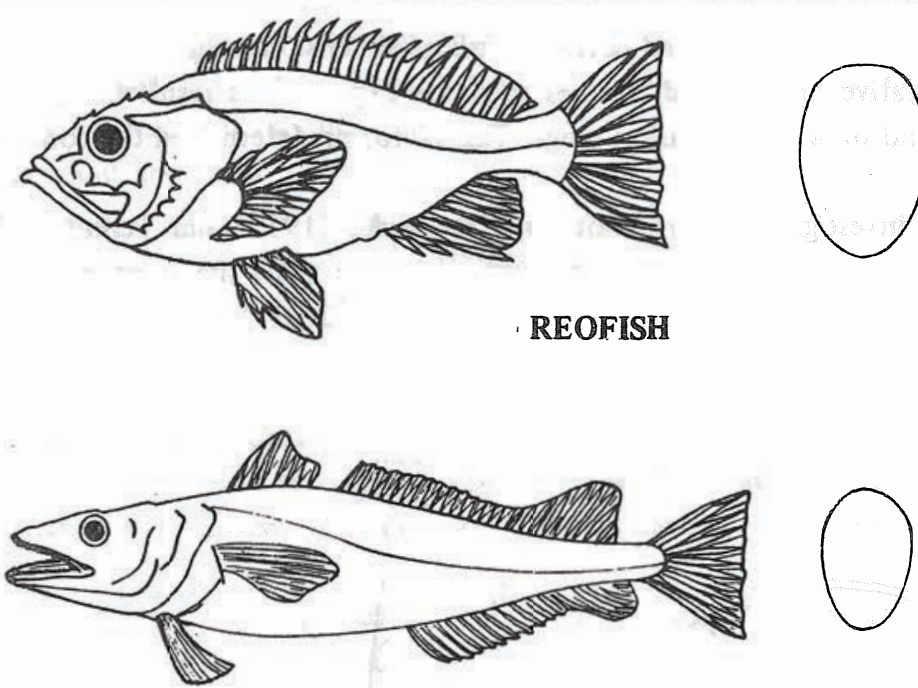

HAKE
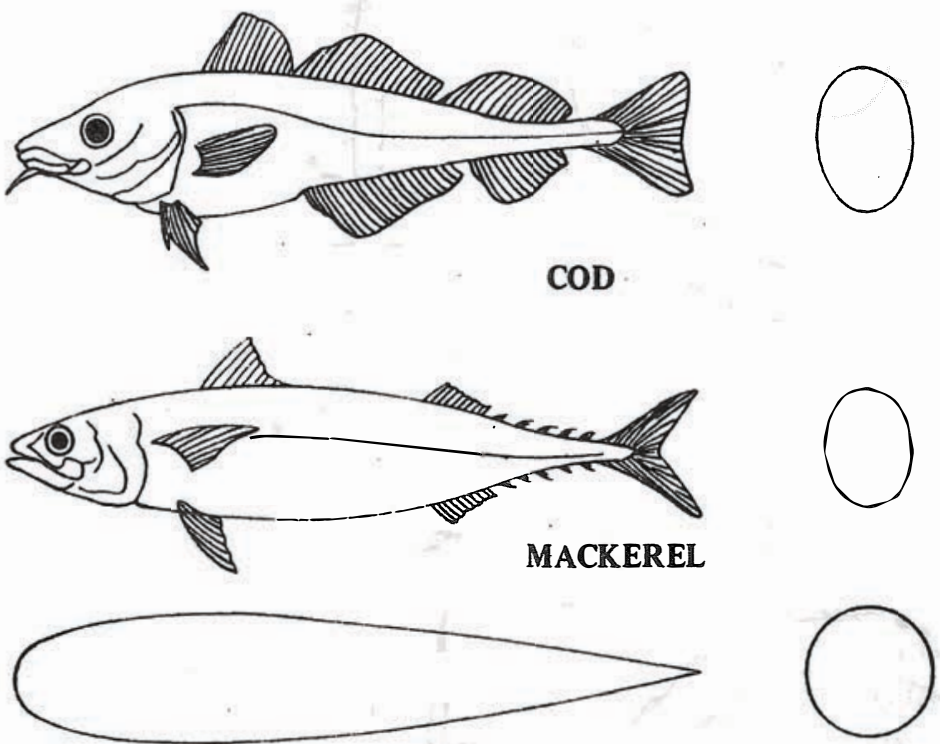

\section{IDEAL STREAM - LINE FORM}

Fig. 2. Comperative sketch for body shapes of investigated fish species

Experiments had been carried-out on the following species: Baltic cod - Gadus morrhua L., and hake - Merluccius merluccius (L.), and partly on Norway haddock Sebastes marinus (L.) and mackerel - Scomber scombrus L. 
For experiments used fresh and defrozen fish of dimensions ranging from 40 to $60 \mathrm{~cm}$.

The quantitative limit of fish species used for experiments resulted from variety of body shapes and of wide dimension range. This factor predetermined the construction of test stand.

Tools. The investigations carried-out by Dormenko (1957) and Terentev (1969) on kinematic analysis of the main cutting units indicate that, the most proper tool for performance of all cutting functions is rotating circular cutter.

An application of circular cutters allows for selection of must simple drive arrangements and for application of the mechanism corrective motions. This, in turn fascilitates to obtain any desires peripherial speed of cutting tool.

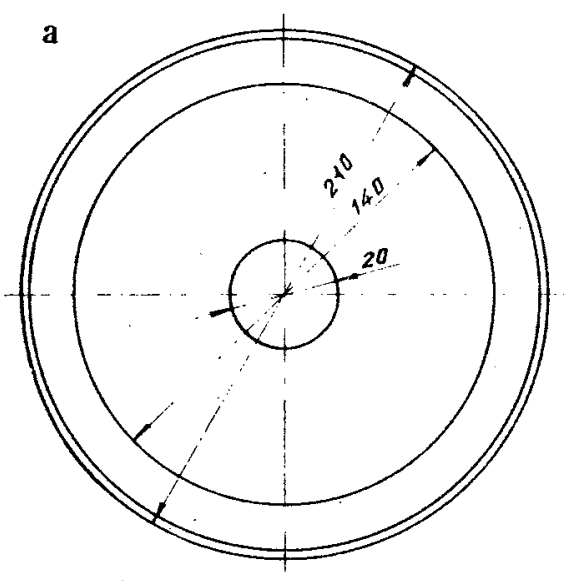

b
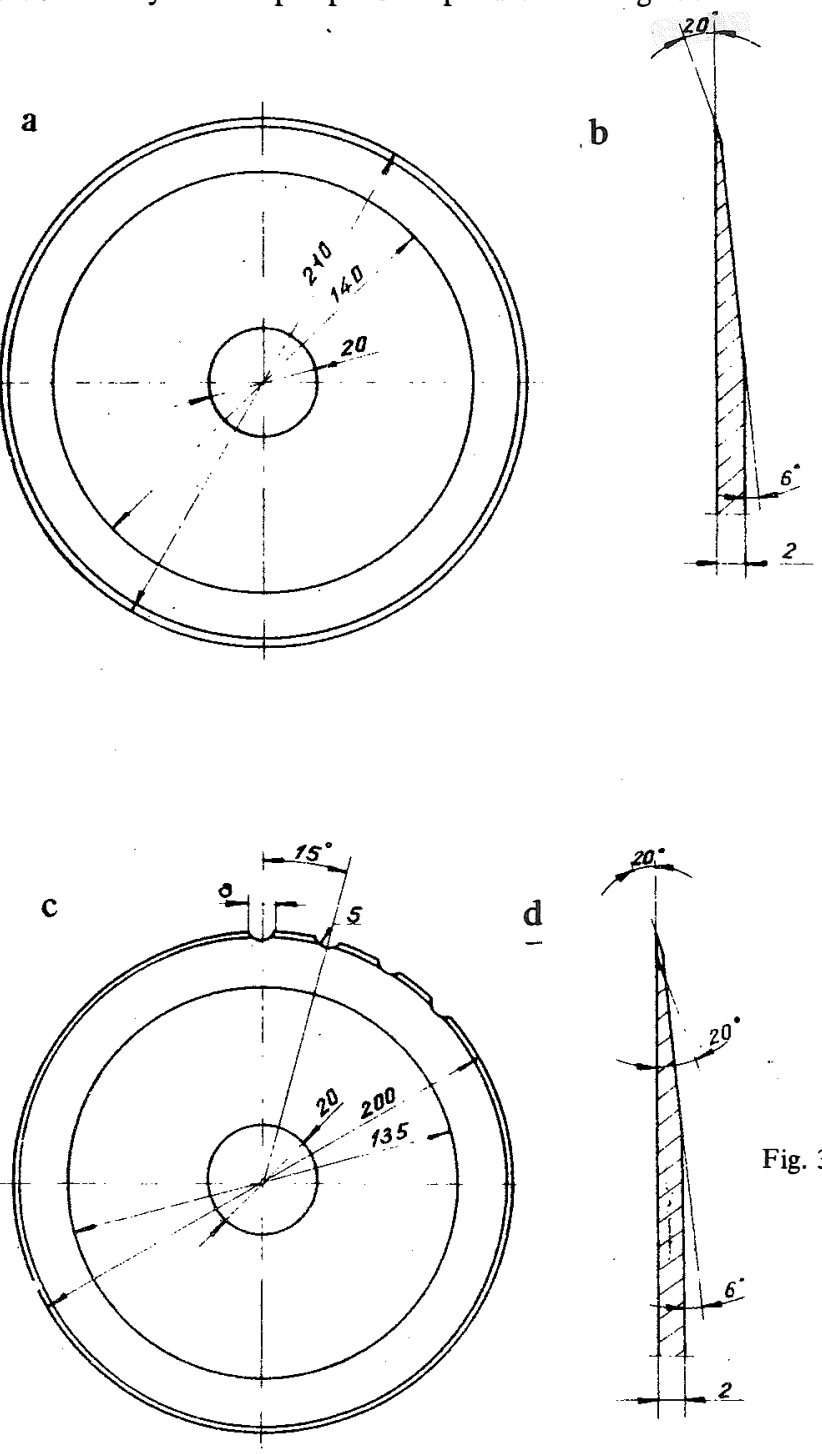

Fig. 3. Cutters used for investigations:
a) plain smooth edge cutter
b) edge profile
c) sector-profile edge cutter
d) edge profile 
The circular cutters used for experiments differed in profile of cutting edge only; some were of smooth plain edge and others, of suitably spaced sector-profile edge. Difference in their diameters was relatively negligeable.

The types and geometric profiles of cutting edges are shown on Fig. 3. The cutters were pointed at one side only. Their diameters were selected in relation to dimension of fish, according to formula specified by Terentev (1969).

Test stand. Of several methods possible, for measurement of cutting forces, selected the method based on the measurements of values changes occuring in electric arrangements of test stand. The worked-out values were determined by indirect method through the measurements and recording of parameters and thenafter through transcalculations.

The selected method was considered as best in view of: installation, costs, recording of measurements, laboriousness in experiments performance, calculation of results and required accuracy.

The test stand (Fig. 4) prepared for experiments, comprised an arrangement for fish transport and an arrangement for fish cutting. All was assembled on table of length $2.5 \mathrm{~m}$.

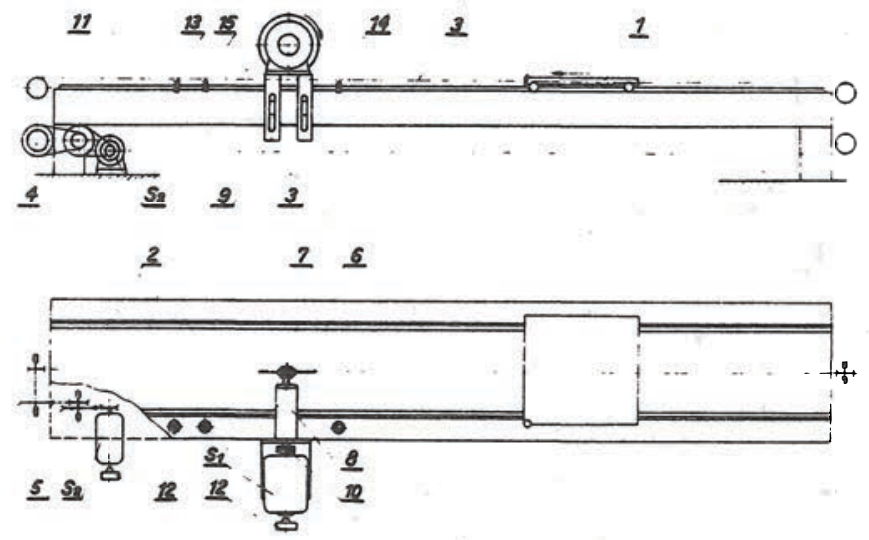

Fig. 4. Diagram of test stand

The transportation arrangement comprised the trolley (1) which on four wheels rolled on rails (2). Trolley was pulled by bushing chain (3) driven by sprocket wheel (4) of the Veebelt transmission(5). All this arrangement was driven by DC elektric motor (2). Travelling speed of trolley (v) was regulated by change of motor rebolution and in experiments, renged from 0.2 to $0.7 \mathrm{~m} / \mathrm{s}$. This speed was selected on analysis of existing speed in fish feeding to the machine. The relatively low values of $v_{p}$ result from the limited possibilities of speed increase in fish feeding to machine. They were also related to kinematic arrangement of transportation, what in practice amounts to 0.5 to $1 \mathrm{~m} / \mathrm{s}$.

The cutting arrangement comprised, the circular cutter (6) fastened on shaft by setting discs (7). The drive shaft was bedded in casing (8) fitted to column (9) and driven from DC electric motor $S_{1}$ through the coupling (10). A spray of water on place of cutting, was applied to minimize the friction. 
Measurement and recording apparatus. An increase of current and of motor rotating speed was automatically registered on photographic tape of oscillograph during the process of cutting. Optical control of measurements was effected on additional electrical instruments and on oscillograph screen.

The complete electric system used for measurement of parameters in cutting process is presented on Fig. 5. To record the changes of measured values, applied on loop-oscillograph (type 8-SO RFT-production) and a range regulator (type $8 \mathrm{MW}-1$ ). Block diagram of the measuring and recording system is given on Fig. 6 .

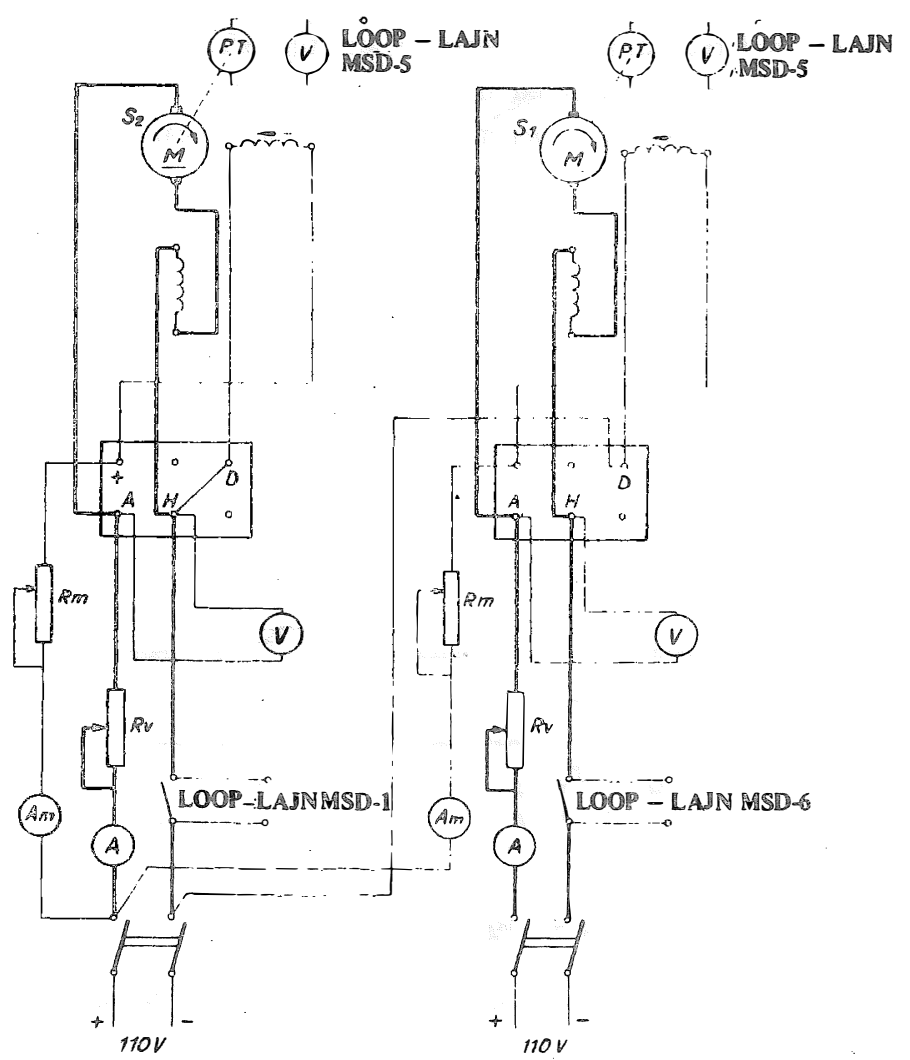

Fig. 5. Electric diagram of test stand

Grounds for the assumed measuring values. The cutting force is a variable value and depends on:

- species, size and qualitative condition of fish,

- localization of cutting on fish body,

- kinematic parameters of cutting process,

- type of cutting tool. 


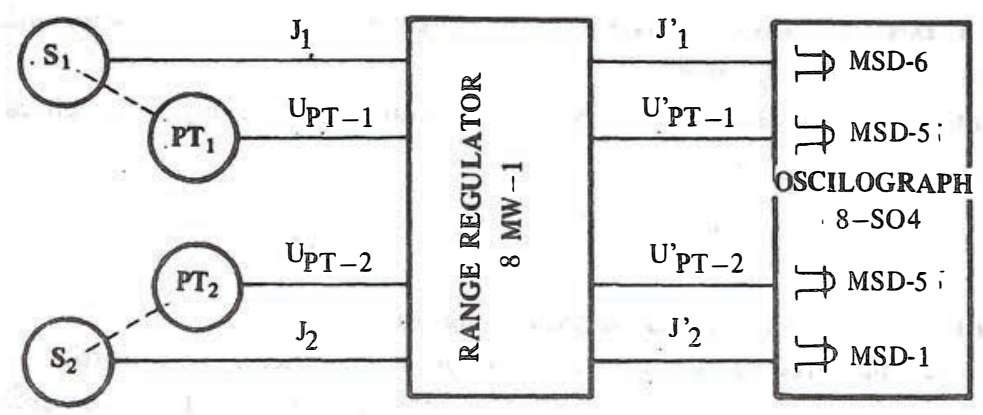

Fig. 6. Block diagram of measuring and recording system

No cutting force can be red directly from the measurements effected. Its value must be obtained through indirect measurements calculated according to proper formulas. The measured electrical values were calculated as components of cutting force $\left(\mathrm{P}_{\mathrm{o}}\right.$ and $\left.\mathrm{P}_{\mathrm{x}}\right)$. Simultaneously, measurements were effected on the remaining components which contribute to calculation formulas (radius of cutter, thickness and mid angle of fish situation). Also, the kinematic parameters of work (rotating speed of cutter and travelling speed of trolley), had to be defined.

The variation value of twisting moment during the work of cutter was balanced by changes in current supply for driving motor. Owing to direct current used for investigations, the measurements of voltage, current and revolutions allowed to determine the value of twisting moment according to the formula:

$$
\mathrm{M}_{1}=\frac{\mathrm{N}_{1}}{0,1047 \cdot \mathrm{n}_{1}}
$$

where:

$\mathrm{n}_{1}$ - number of revolutions of circular cutter (rpm)

$\mathrm{N}_{1}$ - increase of power at cutting moment.

$$
\mathrm{N}_{1}=\mathrm{U}_{1} \cdot \Delta \mathrm{I}_{1}
$$

where:

$\mathrm{U}_{1}$ - current (constant)

$\Delta \mathrm{I}_{1}$ - increase of current.

The peripherial cutting force $\mathrm{P}_{\mathrm{o}}$ was calculated from modified formula into the twisting moment:

$$
P_{0}=\frac{19,1 \cdot U_{1} \cdot \Delta I_{1}}{D \cdot n_{1}}
$$

where:

D - dia of cutter.

The horizontal force $\left(-\mathrm{P}_{\mathbf{x}}\right)$ of sample reaction to cutter, which in direction and value is equal to a component of horizontal cutting force but in opposite direction was 
measured in axis of coordinate system. The effected measurements were analogic to measurement of peripherial force.

For further calculations, used the modified formula 7, according to which calculated the normal component of cutting force $\mathbb{P}_{n}$ :

$$
\mathbb{P}_{\mathrm{n}}=\frac{\mathbb{P}_{\mathrm{o}} \cos \varphi+\mathbb{P}_{\mathrm{x}}}{\sin \varphi}
$$

and from interrelation of 6 , calculated the cutting force $\mathbb{P}$.

The unit cutting force $(p)$ was obtained by division of cutting force through length of cutting arc at the maximum cross-section of sample. The length of arc was definded by measurement of max. height of sample at the moment of cutting.

The measured force of cutting reflects the forces distributed on line of blade, force of friction and of adhesion. The force of friction and adhesion was brought to minimum during the experiments. This was obtained by water spraying and by application of chuck which eliminated any possibility of fish jamming on cutter.

\section{RESULTS}

Basing on the results obtained, it may be ascertained that, the measurements performed according to applied method of cutting speed influence on cutting force, proved to be substantially precise. This permitted to analyse the problem and to draw the constructive conclusions.

The values calculated out of measurements relate to that moment of cutting process when cutter is situated within a fish body and its edge is actually cutting the meat tissue, skin and the bones. These results correspond to the values, which occure in technological processes of fish initial dressing.

The graphic diagrams present the qualitative relation of speed cutting ( $v$ ) to cutting force $(\mathbb{P})$ and allow to estimate the corelation. The speed of cutting was assumed as a variable independent. The value $(\mathrm{v})$ is near to value of peripherial speed on cutting edge $\left(v_{0}\right)$. Speed of fish feeding $\left(v_{p}\right)$ has negligeable effect on change of the resultant value.

The investigated relations are presented in rectangular arrangement of coordinates, within which the approximation of curves was effected by mathematical method. For the unit values, the confidence interval was defined at the assumed probability of 0.90 .

The curves given on Fig. 7 represent the total cutting force which is taking place at beheading of cod and of hake fish. Dimensions of fish are given on diagram. The curves 1 and 2 correspond to work with cutter of smooth uniform cutting edge. Their profile is parabolic. The curves 3 and 4 relate to work with cutter of sector-profiled cutting edge and they run similiarily. The value of variable dependant for all curves is decreasing with and increase of the variable independant.

The minimum cutting force in fresh fish cutting was obtained at speed $\mathrm{v}=22 \mathrm{~m} / \mathrm{s}$, and in cutting of defrozen fish with plain cutting edge, at speed of $17 \mathrm{~m} / \mathrm{s}$. For cutter of sector-profile edge, the minimum cutting force for fresh and defrozen fish was obtained at speed $\mathrm{v}=17-18 \mathrm{~m} / \mathrm{s}$. For these speeds the quality of cutting was good. 


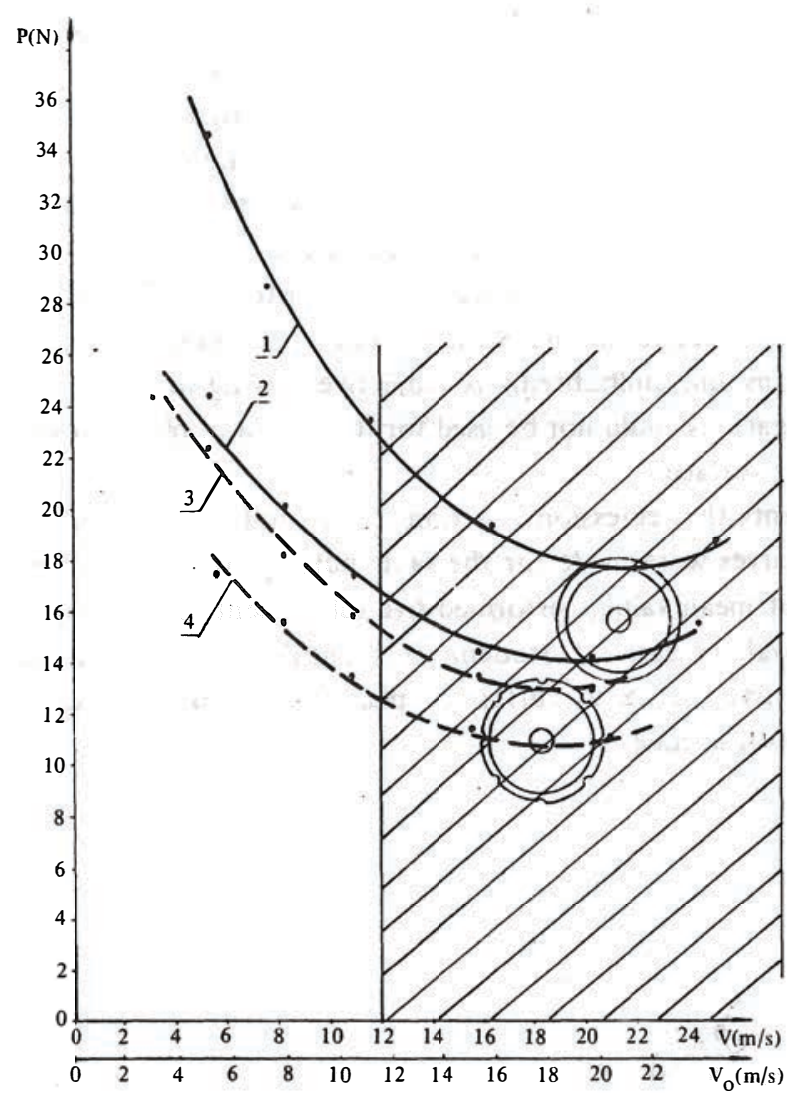

Fig. 7. Correlative dependence of cutting force from cutting speed

The above given values $\mathrm{v}$ must be considered as highest for the particular examined cases.

At higher values of $\mathrm{v}$, curves show the tendency for changing the correlation mark to negative. This may be interpreted as due to considerable increase of friction force between the blade of cutter and material. Under such circumstances an increase of power is required to cover the friction force. The quality of cutting is not changing then. The expected theoritical run of regression function is marked with dotted line. Within total range of the examined cutting speeds, the cutting force for defrozen fish is lower than for fresh fish. These variations amount to about $30 \%$.

Differences in value of cutting force for fresh and defrozen fish is undoubtedly resulting from biochemical changes which take place during the freezing and defreezing process. Meat of defrozen fish looses considerable quantity of cellular liquid what consequently leads to limpy consistence of meat. Due to denaturation, the protein looses its colloidal properties what in turn causes the changes of structural properties. Meat of defrozen fish is easily fraying during the mechanical process of division. 
The quality of cutting is depending on cutting speed. It improves with an increase of such speed, irrespectably of cutting edge profile: and of fish qualitative condition. At speeds lower than $12 \mathrm{~m} / \mathrm{s}$, the cutting quality is not satisfactory (laceration of meat), and at higher speeds, the quality of cutting may be considered as satisfactory. No distinct differences are noted in quality of cutting at further increase of speed (v). On Fig. 7 and 8 , the zone of goodcutting quality is presented by the lined surface.

For estimation of cutting quality ccepted the criterion of visual examination according to principles applied in industrial practice. So presented estimation may cause certain reservations and undoubtedly is subjective. Owing to lack of suitable method, the results of investigations could not be used for formation of obiective estimations as to the quality of cutting surface.

Fig. 8 represents the regression function of the unit cutting force from cutting speed. The particular curves were made for the same cutting conditions as presented on Fig. 7 . For estimation of mean value, performed five subsequent measurements and assumed the confidence interval on basis of Student's $t$ schedule and on calculus coefficient of 0.1 . The continous curves relate to cutters of plain edge, while dotted curves are made for cutter of sector-profile edge.

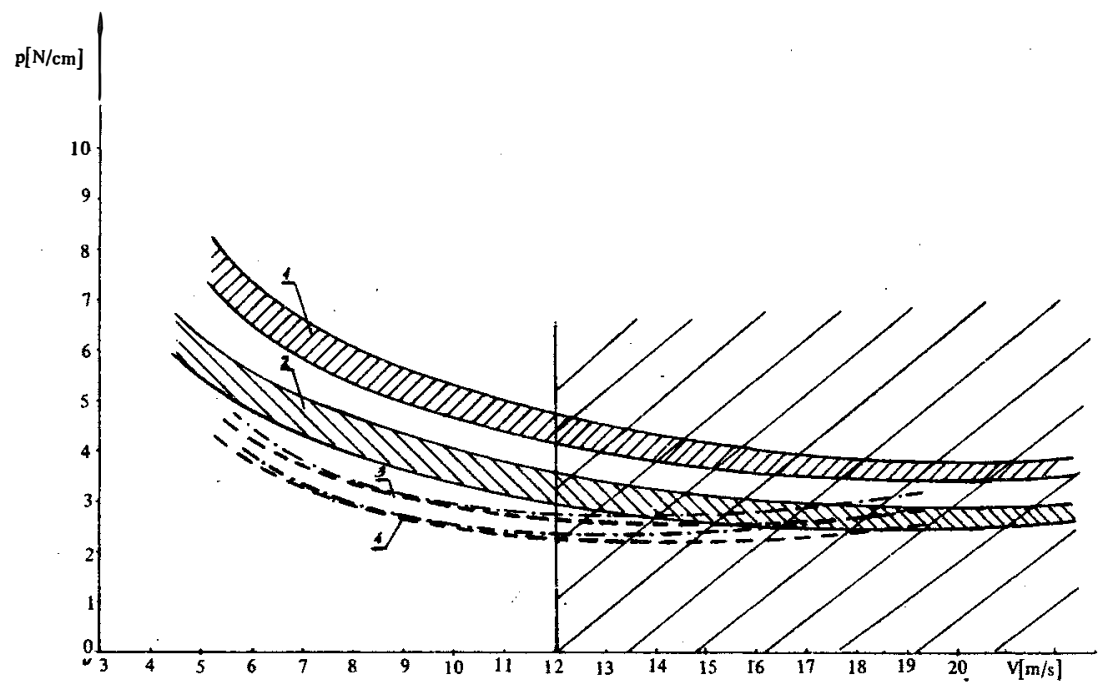

Fig. 8. Curves of correlative dependence of unit cutting force from cutting speed

It may be underlined that for practical purposes, exclusively useful is the value of unit cutting force. This value is adequate for comparisons and for generalizations.

\section{CONCL.USIONS}

The presented results of investigations, however not comprehending the complex of problems related to fish cutting process, may be practically used in designing the machinery for fish processing. The results pertain to work with circular cutters of plain and sector-profile edges. 
The cutting speed has an effect on value of cutting force and any increase of speed lowers this value. Range of best speeds, defined within aspect of good-cutting quality and of minimum force, lies within 12 to $24 \mathrm{~m} / \mathrm{s}$, depending on shape of cutting edge and on species and condition of fish material.

At certain cutting speeds below the defined limits, the quality of cutting is not satisfactory. Good quality of cutting is obtained at minimum cutting speed of $12 \mathrm{~m} / \mathrm{s}$. The value of cutting force is then higher by 10 to $20 \%$ from minimum value obtained at the best speeds.

For practical purposes, the minimum cutting speed should be not lower than the determined best speed. This is due to unkown construction of the fish-feeding chucks, what results in losses on friction.

Owing to relatively small speeds of fish feeding, for practical purposes may be assumed the equation of $\mathrm{v}=\mathrm{v}_{\mathrm{o}}$ and in selection of reąolutions, may be used the condition!

$$
\mathrm{v} \gg \mathrm{v}_{\mathrm{o}}=0,052 \cdot \mathrm{D} \cdot \mathrm{n}
$$

where, for $\mathrm{v}_{\mathrm{o}}$ assumed the values within 12 to $24 \mathrm{~m} / \mathrm{s}$. For fish of tough skin covered with thick scale it is necessary to assume higher values of $\mathrm{v}$. The lower values of $\mathrm{v}$ relate to cod and mackerel species of fish.

The value of unit cutting force for investigated cases within the zone of good-cutting, varied from 2 to $4 \mathrm{~N} / \mathrm{cm}$.

\section{REFERENCES}

Dormenko V.V., 1957: Kinematika osnovnych uzlov ryborazdeločnych mašin. [The kinematics of basie constructions of the fish processing machinery]. Rybnoe Hozjajstvo Moskva.

Jakubov M.A., 1964a: Vlijanie uglovnych parametıov noža na usilie rezanija ryby. [Effect of cutter angular parameters on fish cutting force]. Rybnoe Hozjajstvo, 7: 75-78.

Jakubov M.A., 1964b: Izmenenie udolnych usilij pri rezanii tunca nožom z prijamom iezviem. [Changes of unit forces in tuna-fish cutting with straight-blade cutter]. Rybnoe Hozjajstvo, 9: $62-65$.

Romanov A.A., 1963a: Udelnye nagruzki i režimy raboty režuščego instrumenta ryborazdeločnoj mašiny. [Unit load and operating conditions of cutting tools in fish-cutting machines]. Rybnoe Hozjajstvo, 11: 74-79.

Romanov A.A., 1963b; Udelnoe usilie rezanija ryby i geometrija režuščego instrumenta. [Unit cutting force and geometry of cutting tool]. Rybnoe Hozjajstvo, 12: 51-55.

Strzałkowski A., Sliżyński A., 1969: Matematyczne metody opracowania wyników pomiarów. [Mathematical methods for processing the measurement results]. PWN, Warszawa.

Terentev A.V., 1969: Osnovy kompleksnoj mechanizacii obrabotki ryby. [Basis for compley mechanization in fish processing]. Piščč. Prom. Moskva.

Žilin N.I., 1963: Nekotorye zakonomernosti processa rezanija ryb. [Some relations of process in fish cutting]. Rybnoe Hozjajstvo, 12: 65-68.

Zilin N.İ., 1966: Obosnovanie elementov mechanizacii i avtomatizacii processov razdelki kambal. [Elements of mechanization and automatics in division processes of flat-fish]. Rybnoe Hozjajstvo, 12: 46-50. 
Tadeusz Kawka

\title{
BADANIA NAD USTALENIEM OPTYMALNYCH PARAMETRÓW PRACY NOŻY TARCZOWYCH DO MECHANICZNEJ OBRÓBKI RYB
}

\begin{abstract}
Streszczenie
W pracy przedstawiono badania nad optymalizacją parametrów pracy noży tarczowych służących do mechanicznej obróbki ryb. Do badań zastosowano metodę pomiarów pośrednich, która polegała na pomiarze i rejestracji wielkości elektrycznych. Doświadczenia prowadzono na specjalnie zbudowanym stoisku badawczym.

Stwierdzono, że prędkość krojenia ma wpływ na wartość siły krojenia i na jakość krojenia. Określono optymalny zakres prędkości krojenia niektórych gatunków ryb, dla noży tarczowych o gładkiej i profilowanej krawędzi tnącej. Badania przeprowadzono dla ryb świeżych i rozmrożonych. Określono wartość jednostkowej siły krojenia w zależności od prędkości krojenia.

Przedstawione wyniki badań mogą być praktycznie wykorzystane w projektowaniu maszyn do obróbki ryb.
\end{abstract}

\section{ИССЛЕДОВАНИЯ НАД УСТАНОВ̈ЛЁНИЕМ ОПТИМАЛЬНЫХ ПАРАМЕТРОВ РАБОТЫ КРУГЛЫХ НОЖЕИ ДЛЯ МЕХАНИЧЕСКОМ ОБРАБОТКИ РЫБЫ}

\author{
$\mathrm{P}$ e 3 $10 \mathrm{M}$ e
}

В работе представлены исследования над установлением оптимальных параметров круглых ножей, поименяющихся для механической обработки рыбы. При исследованиях использовали метод косвенных измерений, который заключался в измерении и регистрации электрически величин. Опыты проводили на специально устроенном стенде.

Установлено, что скорость резки рыбы имеет влияние на величину силы резки и на качество резки. Определена взаимозависимость исследуемых величин. Результаты представлены в графиках. Определён оптимальный объём скорости резки некоторых видов рыб для круглых ножей с гладкими и профилирующими режущими краями. Исследования были проведены для свежей и размороженной рыбы. Определены велинины удельной сијы резки в зависимости от скорости резки.

Представленные результаты иссльдований иогут быть использованы практически при проектировании машин для обработки рыбы.

Address:

Received 15 V 1971 r.

Dr Tadeusz Kawka

Instytut Eksploatacji

i Zasobów Morza AR

Szczecin, ul. Kazimierza Królewicza 4

Polska - Poland 